\title{
RADIATION FOR GARLIC PLANLETS ON ACLIMATIZATION PHASE
}

\author{
Dara Cipta Andini' ${ }^{1)}$, Eddy Tri Haryanto ${ }^{2)}$ dan Djoko Purnomo ${ }^{2)}$ \\ ${ }^{1)}$ Mahasiswa Program Studi Agroteknologi Fakultas Pertanian UNS \\ ${ }^{2}$ Program Studi Agroteknologi Fakultas Pertanian UNS \\ Email:daraciptaa@yahoo.com
}

\begin{abstract}
Garlic is one of the important horticultural crops in Indonesia so that the needs increas from year to year. In Indonesia plant material (seed) for cultivating garlic always uses comsumption bulb. The impact of that technique in a long time that the yield gradually decrease by virus infection from preliminary crop. The aim of the research was to find out of seed plant material which virus free by in vitro propagation technology. Acclimatitation is one of succesfuly determination in invitro propagation. Research by the experiment was to study the ability of New Tawangmangu, Gunung Kidul, and Bali garlic varieties on acclimatitation in several light intensity (by paranet shading). The results showed that the totipotency of the garlic varieties was high but in acclimatitation by the shading technique just survived two weeks only. The failure of acclimatitation was range of temperature $12-37^{\circ} \mathrm{C}$.
\end{abstract}

Keywords: garlic, light intensity, shade

\section{PENDAHULUAN}

Bawang putih termasuk tanaman hortikultura penting di Indonesia sehingga kebutuhan dari tahun ke tahun terus meningkat seiring dengan laju pertambahan penduduk (Wibowo 2007). Bawang putih di Indonesia diperbanyak secara vegetatif menggunakan umbi yang secara teoritis tidak akan mengalami perubahan genetik. Namun kemudian teknologi tersebut terbukti mengakibatkan penyakit degeneratif oleh virus sehingga pertumbuhan, produksi, dan kualitas hasil umbi bawang putih terus turun.

Lokasi yang semula sebagai pusat produksi terus mengalami penyusutan hasil baik kuantitas maupun kualitas. Salah satu penyebab penurunan produktivitas bawang putih adalah pathogen berupa virus. Virus pada bawang putih adalah shallot latent virus (SLV) dan onion yellow dwarfus (OYDV) (Brewster 2002; Fletcher et al. 1998). Virus mengakibatkan penurunan hasil $60 \%$. Penelitian Ikeda dan Imamoto di tahun 1991, menyatakan bahwa penggunaan umbi lapis bibit bebas virus dapat meningkatkan hasil lebih dari $60 \%$ pada beberapa kultivar (Fletcher et al. 1998).

Untuk mengatasi hal tersebut diperlukan usaha penyediaan bibit yang bebas virus. Secara konvensional bibit bawang putih bebas virus sulit dikembangkan, selain itu penyediaan bibit dalam jumlah besar membutuhkan waktu lama dan lahan yang luas
(Nugroho dan Sugito 2000). Dalam rangka memenuhi bibit berkualitas dalam jumlah banyak dan terus menerus telah berkembang teknik perbanyakan mikro melalui kultur jaringan.

Kultur jaringan merupakan suatu usaha dediferensiasi sekaligus diferensiasi tanaman berasal dari bagian meristematik, kemudian ditumbuhkan secara mandiri dengan memanfaatkan sifat totipotensi sel. Reaktivitas pertumbuhan dan diferensiasi sel menjadi tanaman lengkap tergantung kepada suplai nutrisi, zat pengatur tumbuh, dan manipulasi lingkungan (George dan Sheriton, 1984; Pierik, 1987). Cara ini menjanjikan berbagai keuntungan konvensional yaitu menghasilkan bibit secara massal, bebas dari patogen, sifat sama dengan induk, dan pelaksanaan tidak tergantung pada iklim dan musim. Penggunaan bagian meristematik yang aktif membelah dan terlindung dari pengaruh luar secara langsung memungkinkan tanaman cepat berkembang dan bebas patogen.

Bahan atau bibit hasil perbanyakan invitro (plantlet) memerlukan aklimatisasi sebelum ditanam di lapangan. Oleh karena itu aklimatisasi merupakan kegiatan akhir teknik kultur jaringan, tidak lain adalah proses pemindahan planlet dari lingkungan yang terkontrol (aseptik dan heterotrof) ke kondisi lingkungan tak terkendali, baik suhu, cahaya, dan kelembaban. Masa aklimatisasi merupakan masa kritis karena pucuk in vitro sangat peka terhadap transpirasi, infeksi jamur 
dan bakteri, intensitas cahaya dan suhu tinggi. Proses aklimatisasi plantlet memerlukan penanganan yang cermat, antara lain berupa modifikasi kondisi lingkungan terutama suhu, kelembaban, dan cahaya.

Cahaya berperan penting dalam mengendalikan pertumbuhan, seperti laju dan diferensiasi, yang terekspresikan dalam perkembangan struktur atau morfogenesis (Economou and Read 1987; Salisbury dan Ross 1995). Cahaya mempengaruhi laju pemanjangan, penebalan batang, jumlah buku dan morfologi tunas mikro (Hussey and Stacey 1981). Penelitian ini bertujuan untuk mempelajari kemampuan daya aklimatisasi bawang putih varietas Tawangmangu Baru, Gunung Kidul, dan Bali, serta mempelajari intensitas cahaya yang sesuai.

\section{BAHAN DAN METODE}

Penelitian dilaksanakan bulan FebruariApril 2014 di Laboratorium Fisiologi dan Bioteknologi Tumbuhan, Fakultas Pertanian Universitas Sebelas Maret Surakarta (7³3'39,5" LS dan 110 51'31,4" BT) (kultur invitro) dan di screen house di Dukuh Pancot (aklimatisasi) terletak pada $\left(7^{\circ} 39^{\prime} 25,4^{\prime \prime}\right.$ LS dan $111^{\circ} 8^{\prime} 31,9^{\prime \prime}$ BT), elevasi $1218 \mathrm{~m}$ diatas permukaan laut (dpl). Percobaan dilakukan dengan dua faktor perlakuan, faktor pertama adalah intensitas cahaya (100\% atau terbuka, 50 , dan $25 \%$ naungan), faktor kedua adalah varietas bawang putih (Gunung Kidul, Tawangmangu Baru, dan Bali).

Penelitian dimulai dari kultur invitro diawali sterilisasi alat menggunakan autoklaf, alkohol, dan spirtus. Eksplan (cakram umbi bawang) ditanam pada media MS (dalam botol kultur) mengandung ZPT dan hara (makro dan mikro). Tanaman kultur disimpan dalam ruang dengan suhu $20^{\circ} \mathrm{C}$ sampai terbentuk akar, tunas, dan daun atau plantlet (lebih kurang 3 minggu). Planlet kemudian dikeluarkan dari dalam botol untuk aklimatisasi. Setelah plantlet dikeluarkan dari dalam botol lalu dibilas dengan air bersih dan segera ditanam pada media campuran tanah dan pupuk organik 2:1 (dalam kantong plastik). Media tersebut diatur ditempatkan tanpa naungan (1795 Candle/Cd), 50\% (1494 Cd), dan 25\% (854 Cd). Planlet pada media kemudian disungkup plastik untuk menghindari hama. Pengamatan aklimatisasi dilakukan selama tiga minggu.
Variabel penelitian pada in vitro adalah tingkat keberhasilan (kematian dan jumlah tanaman) sedangkan pada aklimatisasi adalah kondisi planlet, tinggi tanaman, jumlah daun, dan tingkat kematian. Data yang diperoleh dianalisis menggunakan analisis deskriptif berdasar tabulasi dan gambar.

\section{HASIL DAN PEMBAHASAN}

\section{Kondisi planlet}

Kondisi plantlet bawang putih varietas Gunung Kidul, Tawangmangu Baru, dan Bali saat awal aklimatisasi, masing-masing setinggi $16,90,14,92,10,58 \mathrm{~cm}$, daun berjumlah 4,04, 3,66, dan 1,85 helai, dan jumlah akar 3,04, 2,85 , dan 2,47 . Ini menunjukkan bahwa secara invitro pertumbuhan eksplan bawang putih varietas Gunung Kidul relatif lebih baik daripada Tawangmangu Baru, dan Bali, namun totipotensi sel tiga varietas tersebut dapat dinyatakan hampir sama. Pertumbuhan pada akhir kultur invitro menjadi modal keberhasilan aklimatisasi. Keberhasilan aklimatisasi peran perakaran, kondisi tanaman saat akhir kultur invitro (eksplan baru dikelurkan dari botol), kemampuan tanaman dalam mengendalikan kondisi lingkungan, dan media tumbuh di lapangan sangat besar (Imelda et al. 2007). Dengan demikian berdasarkan fakta tinggi dan jumlah daun serta akar tersebut semestinya ketiga varietas berpotensi tinggi dalam aklimatisasi.

\section{Iklim mikro}

Suhu udara maksimum diatas tanaman tak ternaungi maupun ternaungi hampir sama (sekitar $37^{\circ} \mathrm{C}$ ), sedangkan suhu minimum disekitar tanaman tak ternaungi dan ternaungi $50 \%$ berkisar $12^{\circ} \mathrm{C}$, ternaungi $75 \%$ sebesar $11,75^{\circ} \mathrm{C}$, dapat dikatakan tidak berbeda jauh. Suhu maksimum dan minimum tersebut (sekitar $12-37^{\circ} \mathrm{C}$ ) sedikit diluar rentang suhu optimum untuk pertumbuhan bawang putih (20-30 $\left.{ }^{\circ} \mathrm{C}\right)$. Suhu menjadi salah satu faktor penentu pertumbuhan dan perkembangan tanaman. Hasil penelitian Reijnders, Suwandi, dan Stallen (1991) menunjukkan bahwa pengaruh agroklimat terhadap pertumbuhan kultivar bawang putih sangat dipengaruhi oleh lokasi penanaman. Perubahan suhu dari kultur invitro $\left(25 \pm 1^{\circ} \mathrm{C}\right)$ ke invivo yang dapat mencapai $18^{\circ} \mathrm{C}$ pada malam hari dan $32^{\circ} \mathrm{C}$ pada siang hari berakibat terhadap pertumbuhan planlet yang tertekan sehingga aklimatisasi sering mengalami kegagalan. 
Oleh karena itu suhu lingkungan saat awal aklimatisasi diusahakan mendekati suhu invitro, kemudian secara bertahap ditingkatkan seiring dengan pertumbuhan tanaman.

Kelembaban udara berhubungan erat dengan radiasi matahari (intensitas cahaya). Kelembaban udara relatif dibawah naungan paranet $75 \%$, 50\%, dan tak ternaungi (854, 1494, dan 1795 Candle/Cd) masing-masing $81,53,79,64$, dan $78,67 \%$. Ini menunjukkan bahwa intensitas cahaya semakin rendah kelembaban udara semakin tinggi seperti fenomena normal. Kelembaban relatif tersebut masih dalam kisaran optimum untuk pertumbuhan bawang putih, 80-90\% (Reijnders, Suwandi, dan Stallen 1991). Planlet hasil mikropropagasi terbiasa hidup di kelembapan udara berkisar 90-100\%. Kondisi tersebut berakibat planlet tidak mengembangkan sistem pertahanan dalam menghadapi cekaman kekeringan. Selain itu kelembaban udara dan kelembaban tanah yang relatif tinggi (> 90\%) dapat merangsang infeksi penyakit. Angin sepoi-sepoi berpengaruh baik terhadap pertumbuhan dan pembentukan umbi bawang merah. Untuk itu saat aklimatisasi dilakukan penurunan kelembaban udara secara bertahap (menggunaka sungkup yang dibuka secara bertahap). Berdasarkan fakta diatas diantara faktor iklim mikro (suhu, intensitas cahaya, dan kelembaban) hanya suhu yang kurang optimum untuk aklimatisasi plantlet bawang merah.

\section{Penampilan tanaman}

Aklimatisasi sampai dengan dua minggu tinggi tanaman varietas Gunung Kidul dan Tawangmangu Baru masing-masing mencapai 17,5 dan $17,91 \mathrm{~cm}$ dibawah naungan $75 \%$. Bawang putih varietas Bali tinggi tanaman mencapai 16,66 $\mathrm{cm}$ dibawah naungan 50\% (tabel 1). Tinggi tanaman menunjukkan bahwa peran naungan (intensitas cahaya) sangat besar. Tanaman menerima cahaya rendah, lebih tinggi daripada tanaman menerima cahaya tinggi. Tinggi tanaman sebagai ekspresi pemanjangan dan pembesaran sel yang secara internal dikendalikan oleh auksin. Aktivitas auksin antagonis dengan cahaya, cahaya rendah auksin aktif (tanaman memanjang) dan sebaliknya bila intensitas cahaya tinggi (Purnomo et al. 2008; Taiz and Zieger 2010). Naungan sebagai upaya manipulasi untuk memperoleh cahaya, kelembaban, dan suhu optimum. Seperti pernyataan di pembahasan suhu (suhu lebih rendah dan lebih tinggi daripada suhu optimum), maka naungan berperan besar terhadap tinggi tanaman karena secara umum tanaman rentan terhadap suhu tinggi (Magfoer dan Koesriharti 1998). Semua varietas tumbuh baik dibawah naungan dibandingkan dengan tanpa naungan. Penelitian Marjenah (2001) pada Shorea pauciflora dan S. Selanica mendapatkan fakta bahwa tinggi dan diameter tanaman dipengaruhi oleh cahaya. Pertumbuhan tanaman lebih cepat pada tempat ternaungi dibanding tempat terbuka. Namun demikian bila intensitas cahaya terlalu rendah, maka suhu juga sangat rendah sehingga pertumbuhan tanaman terhambat (Santoso 2010).

Tabel 1. Kematian saat akhir aklimatisasi, tingi tanaman dan jumlah daun umur 1 dan 2 minggu

\begin{tabular}{ccccccc}
\hline Varietas & $\begin{array}{c}\text { Cahaya, Cd, } \\
(\text { naungan, \%) }\end{array}$ & $\begin{array}{c}\text { Kematian } \\
(\%)\end{array}$ & $\begin{array}{c}\text { Tinggi tan. } \\
\text { umur 1mg } \\
(\mathrm{cm})\end{array}$ & $\begin{array}{c}\text { Jumlah } \\
\text { daun }\end{array}$ & $\begin{array}{c}\text { Tinggi tan. } \\
\text { umur 2 mg } \\
(\mathrm{cm})\end{array}$ & $\begin{array}{c}\text { Jumlah } \\
\text { daun }\end{array}$ \\
\hline \multirow{3}{*}{ Gunung Kidul } & $1795(0)$ & 14,28 & 8,14 & 1,85 & 15,0 & 3,16 \\
& $1484(50)$ & 14,28 & 11,71 & 2,42 & 16,58 & 3,28 \\
Tawangmangu & $854(25)$ & 0,0 & 11,21 & 2,16 & 17,50 & 3,0 \\
Baru & $1795(0)$ & 28,57 & 8,94 & 2,20 & 16,30 & 3,0 \\
& $1484(50)$ & 28,57 & 10,26 & 2,33 & 17,50 & 3,16 \\
Bali & $854(25)$ & 14,28 & 11,33 & 1,20 & 17,91 & 2,60 \\
& $1795(0)$ & 28,57 & 12,72 & 1,85 & 15,54 & 2,40 \\
& $1484(50)$ & 14,28 & 14,34 & 2,71 & 16,66 & 2,83 \\
\hline
\end{tabular}

Keterangan: Cd: Candle, tan: tanaman, mg: minggu 
Berdasarkan data (tabel 1) peningkatan jumlah daun dari umur satu minggu ke dua minggu berkorelasi dengan peningkatan tinggi tanaman ( $\mathrm{r}: \pm 0,5)$. Setelah minggu kedua penambahan daun tidak terjadi kemudian mati. Jumlah daun ketiga varietas tertinggi $(3,28$, 3,16 , dan 2,83) pada naungan 50\%. Tanpa naungan jumlah daun lebih sedikit, ini sesuai dengan tinggi tanaman. Daun tumbuh dari tunas pada buku sehingga tanaman yang lebih rendah, jumlah buku lebih sedikit, demikan pula jumlah daun.

\section{Kematian pada aklimatisasi}

Kematian dimaksud di sini adalah plantlet yang tidak tumbuh saat aklimatisasi telah berlangsung. Saat awal aklimatisasi plantlet semua varietas yang telah tumbuh (berdaun dan berakar) di kultur invitro, daun layu dan mati. Setelah beberapa saat plantlet membentuk tunas baru kemudian tumbuh, plantlet yang tidak tumbuh lagi dikategorikan mati. Saat aklimatisasi umur 2 minggu varietas Gunung Kidul memiliki daya aklimatisasi paling tinggi. Tanpa naungan dan naungan $50 \%$ kematian sebesar $14,28 \%$ dan pada naungan $75 \%$ semua tanaman masih bertahan. Tingkat kematian varietas Tawangmangu Baru sebesar $28,5 \%$ pada intensitas cahaya penuh dan naungan $50 \%$, sedangkan pada naungan $75 \%$ persentase kematian hanya $18,28 \%$. Pada varietas Bali dibawah cahaya rendah (naungan 75\%) semua tanaman hidup, namun pada intensitas cahaya penuh dan naungan $50 \%$ semua mengalami kematian. Semua varietas pada minggu ketiga semua mati. Seperti yang dikemukakan pada bahasan iklim mikro bahwa kisaran suhu tempat aklimatisasi $\left(12-37^{\circ} \mathrm{C}\right)$ lebih lebar daripada kisaran suhu optimum $\left(20-30^{\circ} \mathrm{C}\right)$. Dengan demikian hasil penelitian ini tidak sesuai dengan pernyataan Imelda (2007) bahwa keberhasilan aklimatisasi ditentukan oleh kondisi tanaman saat akhir kultur invitro (eksplan baru dikelurkan dari botol). Totipotensi semua varietas bawang putih dapat dikatakan tinggi namun hanya bertahan hingga dua minggu saat aklimatisasi (ini merupakan kekhasan bawang putih) (tabel 1).

\section{KESIMPULAN DAN SARAN}

Bawang putih varietas Gunung Kidul, Tawangmangu Baru, dan Bali memiliki totipotensi yang tinggi, namun aklimatisasi melalui pengaturan intensitas cahaya menggunakan paranet hanya berhasil sampai dengan dua minggu. Penampilan plantlet bawang putih berdasarkan tinggi, jumlah daun, dan jumlah akar yang dikategorikan baik, tidak menjamin keberhasilan aklimatisasi menggunakan teknologi naungan dengan paranet, suhu berkisar antara $12-37^{\circ} \mathrm{C}$ sebagai penyebab kegagalan aklimatisasi

Sebagai saran, aklimatisasi untuk bawang putih memerlukan adaptasi secara bertahap dengan mencoba menggunakan sungkup yang secara berkala dibuka.

\section{DAFTAR PUSTAKA}

Alrasyid H. 2000. Percobaan penanaman padi gogo di bawah tegakan hutan tanaman acacia mangium di BKPH Parung Panjang, Jawa Barat. Buletin Penelitian Hutan no. 621. Hal 27-54.

Brewster J.L. 2002. Onion and other vegetable alliums. Cab. International. Cambridge.

Economou A.S., and P.E. Read. 1987. Light treatment to improve efficiency of in vitro propagation. Hurtscience 22(5): 751-754.

Evans D. A., W. R. Sharp, and C. E. Flick. 1981. Growth and behavior of cell culture: embriogenesis and organogenesis. Dalam Thorpe, T. A., Plant Tissue Culture, Methodes and Applications in Agriculture. Academic Press, New York.

Fletcher G.C., G. Summers, and P.W.C van Veghel. 1998. Level of histamine and histamine producing bacteria in smoked fish from New Zealand market.J. Food. Prot. 61(8):1064-1070.

Gardner F.P., R.B. Pearce, dan R. L. Mitchell. Terjemahan oleh H. Susilo, Gunaeni, Neni, dan A.K. Karjadi. 2008. Kultur meristem dan antiviral ribavirin pada tanaman kentang. Jurnal Agrivigor 7(2): 105-112.

George E.F., M.A. Hall, Imelda dan G.J. de Klerk. 2007. Plant propagation by tissue culture. $3^{\text {rd }}$ Edition. Vol 1.The Background. Springer, The Netherland. $504 \mathrm{p}$.

Hussey G. and N.J. Stacey.1981. In vitro propagation of potato (Solanum tuberosum). Ann. Bet. 48; 787-796. 
Nugroho A. dan H. Sugito. 2000. Pedoman Pelaksanaan Teknik Kultur Jaringan. Jakarta: Penebar Swadaya.

Purnomo D., A.T. Sakya, dan M. Rahayu. Fisiologi Tumbuhan, Dasar Ilmu Pertanian. Sebelas Maret University Press. Surakarta.

Reijenders, Suwandi, Stallen. 1991. Pengaruh lokasi ketinggian tempat terhadap pertumbuhan dan perkembangan bawangputih cv. Lumbu Putih dan Lumbu Kuning. Laporan Penelitian. ATA 395 Project.

Reiley H.E., C.L.J. Shry. 1979. Introductory Horticulture. Delmar Publisher. Albany. New York.
Salisbury, F.B., dan C.W. Ross. 1995. Fisiologi tumbuhan III. Penerbit ITB Bandung. 343 hal.

Taiz L. and E. Zieger. 2010. Plant Physiology on line. Creat by Sinauer.

Takagi and C. I. M. de Visser,. 1998. Effect of Split Application of Nitrogen on Yield and Nitrogen Recovery of Spring-sown Onions and on Residual Source. J. Of Horticultural Science and Biotech. 73: 403-411.

Wibowo S. 2007. Budidaya Bawang Merah, Bawang Putih, dan Bawang Bombay. Penebar Swadaya. Jakarta. 